\title{
Extraction of Vanadium from an Industrial Waste
}

T.K. Mukherjee and C.K. Gupta

Metallurgy Division,

Bhabha Atomic Research Centre, Bombay 400 085, India

\section{CONTENTS}

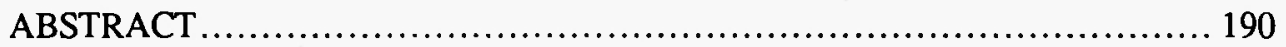

1. INTRODUCTION .................................................... 190

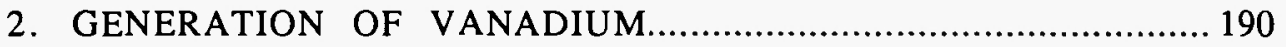

3. SOLUTION PURIFICATION........................................... 192

4. PRECIPITATION OF VANADATE SALTS ............................... 193

A. Sodium Hexavanadate ........................................... 193

B. Ammonium Metavanadate .......................................... 193

C. Ammonium Hexavanadate................................................ 194

D. Calcium Vanadate..................................................... 194

E. Ferrous Vanadate ................................................... 195

5. CONVERSION OF VANADIUM COMPOUNDS

TO METALLIC PRODUCTS............................................... 195

A. Ferrovanadium................................................... 196

B. Vanadium-Aluminium Alloys ........................................ 198

6. REFINING OF VANADIUM-ALUMINIUM ALLOYS

TO DUCTILE GRADE VANADIUM ................................... 201

A. Electron Beam Melting............................................ 201

B. Fused Salt Electron Refining ........................................ 201

7. CONCLUSIONS ...................................................... 203

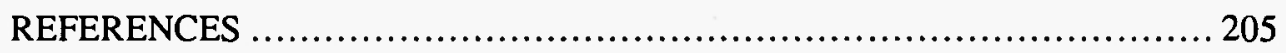




\begin{abstract}
Vanadium-bearing Bayer sludge, an industrial waste generated during recovery of alumina from bauxite, is widely recognised as an important secondary resource of vanadium. Processes for the extraction of vanadium in the form of compounds, alloys and metal from such a source essentially forms the subject matter of this paper. The theory and practice of precipitation of various vanadate salts like sodium hexavanadate, ammonium metavanadate, ammonium hexavanadate, calcium vanadate and ferrous vanadate by chemically processing the vanadium-bearing alkaline solutions generated from water leaching of vanadium sludges are described first. Conversion of these chemically produced vanadate compounds into ferrovanadium and vanadium-aluminium alloys by using an aluminothermic reduction technique is next presented. Finally, postreduction refining techniques like electron beam melt refining with or without a prior pyrovacuum treatment in the solid state and molten salt electrorefining process are described for obtaining ductile grade vanadium metal from various grades of aluminothermically prepared vanadium intermediates.
\end{abstract}

\section{INTRODUCTION}

The various resources of vanadium can be broadly classified /1/ as primary, by- or co-products and industrial wastes. Primary resources are processed solely for vanadium and include ores containing vanadium minerals like patronite, bravoite, sulvanite, elavidite and roscoelite as well as materials like clay. The by- or co-product group of vanadium resources are not worked exclusively for vanadium but also for other elements like uranium, iron, titanium, phosphorous, etc. and include carnotite, titaniferous magnetite, vanadiferous iron ores and phosphate rocks. Finally, a host of industrial wastes like flyash from oil combustion, spent catalysts generated during desulphurisation of crude oils, waste sulphate liquor from the $\mathrm{TiO}_{2}$-based pigment manufacturing plants, slime tailings generated during beneficiation of the phosphate ore and vanadium-bearing sludge rejected during the treatment of bauxite ore by the Bayer process happen to contain vanadium in significant concentrations to warrant recovery.
Among the various industrial wastes mentioned above, Bayer sludges from aluminium extraction plants are quite rich in vanadium and, therefore, stand as a highly attractive vanadium resource in countries like the USSR, France, Turkey and India, all of which have bauxite ores associated with vanadium pentoxide. In the present paper, an effort is made to describe the mode of generation of this type of vanadium resource, purification of the leach liquor formed by water leaching of the sludge, precipitation of various vanadate salts from the purified solution, conversion of these salts to vanadiumbearing metallic products and finally refining these reduced vanadium metallic products to ductile grade metal.

\section{GENERATION OF VANADIUM SLUDGE}

Bauxite ore is generally associated with varying quantities of $\mathrm{TiO}_{2}, \mathrm{Fe}_{2} \mathrm{O}_{3}, \mathrm{SiO}_{2}, \mathrm{CaO}, \mathrm{P}_{2} \mathrm{O}_{5}$, etc. Bauxite ores found in the USSR, France, Turkey and India are also known to carry 0.01 to $0.056 \%$ vanadium as an oxide. Bauxite ore is universally treated by the Bayer process (Fig. 1) which yields pure $\mathrm{Al}_{2} \mathrm{O}_{3}$ and also always yields an unreacted residue called red mud and sometimes a second waste in the form of vanadium sludge if the oxide is associated with $\mathrm{V}_{2} \mathrm{O}_{5}$. During the caustic soda digestion of bauxite, about 25 to $30 \%$ of vanadium and phosphorous present in the ore gets codissolved along with aluminium minerals. The insoluble residue (red mud) which contains the undissolved part of bauxite and unrecoverable alkali is generated at a rate of 0.3 to $0.4 \mathrm{~T}$ for every ton of bauxite processed. A typical analysis of a red mud from an Indian aluminium plant is $\mathrm{Fe}_{2} \mathrm{O}_{3} 35.5, \mathrm{Al}_{2} \mathrm{O}_{3} 23, \mathrm{TiO}_{2}$ 17.2, $\mathrm{SiO}_{2} 5, \mathrm{Na}_{2} \mathrm{O} 4.8$ and $\mathrm{V}_{2} \mathrm{O}_{5} 0.34$ in weight percent. The leach liquor after separation from the red mud is treated for the precipitation of aluminium hydroxide. The vanadium value present in the leach liquor does not precipitate initially along with $\mathrm{Al}(\mathrm{OH})_{3}$ but as its concentration gradually builds up due to recycling of the caustic liquor, a stage is reached when vanadium acts as a poison in the growth of the hydrated alumina seeds and adversely influences the process efficiency. Moreover, if the vanadium in the circuit is carried over to the final aluminium metals, it will bring down the electrical 


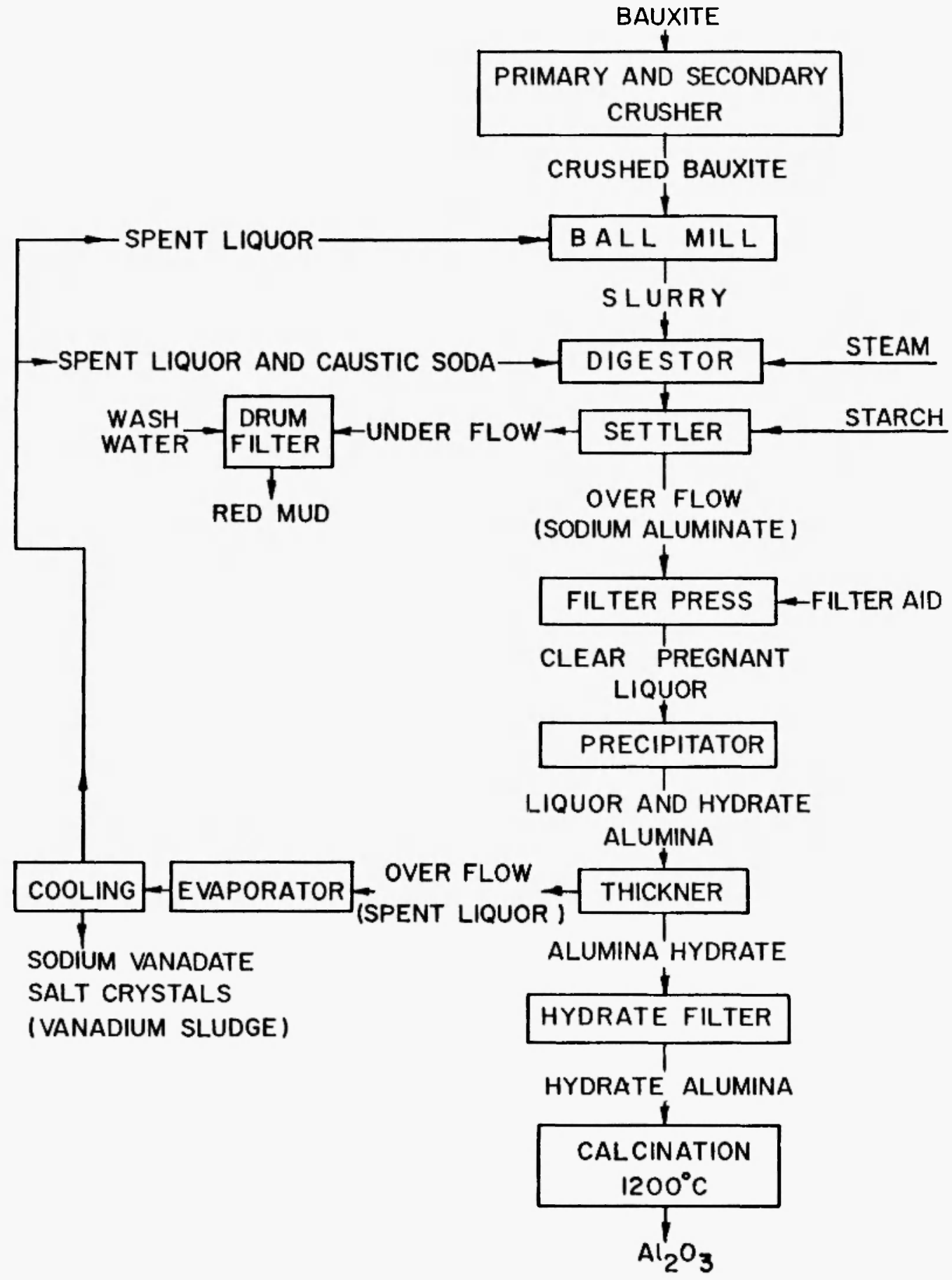

Fig. 1: Bayer process for the recovery of $\mathrm{Al}_{2} \mathrm{O}_{3}$ and vanadium sludge from vanadium bearing bauxite ore. 
conductivity significantly. It is, therefore, mandatory to separate the excess vanadium from the circuit by cooling down the liquor to below $25^{\circ} \mathrm{C}$ at which point a complex sodium vanadate salt of formular $2 \mathrm{Na}_{3} \mathrm{VO}_{4}$, $\mathrm{NaF}, 19 \mathrm{H}_{2} \mathrm{O}$ along with an isomorphous compound of phosphorous precipitates out.

This complex vanadium salt is sandy in texture and contains 5 to $20 \mathrm{wt} \% \mathrm{~V}_{2} \mathrm{O}_{5}$ besides free alkali, phosphate, silica, alumina and fluoride. The sodium complex salt generated by the M/s. Indian Aluminium Co. (INDALCO) located in the eastern part of India, for example, contains $15 \% \quad \mathrm{~V}_{2} \mathrm{O}_{5}$ and $3 \% \mathrm{P}_{2} \mathrm{O}_{5}$. The vanadium sludge from the Hindustan Aluminium Co. (HINDALCO) located in the northern part of India is produced at a rate of $1000 \mathrm{~T} / \mathrm{year} / 2 /$ and is relatively richer in its vanadium content which has been analysed as $17.5-18 \% \mathrm{~V}_{2} \mathrm{O}_{5}$ and 1 to $1.2 \% \mathrm{P}_{2} \mathrm{O}_{5}$. The Bharat Aluminium Company (BALCO), yet another Indian producer of aluminium, on the other hand, rejects vanadium sludge containing only 5 to $9 \% \mathrm{~V}_{2} \mathrm{O}_{5}$.

Irrespective of the grade of the sludge, water leaching yields a vanadium-bearing alkaline solution that carries sodium phosphate as an undesirable impurity.

Depending on the $\mathrm{V}_{2} \mathrm{O}_{5}$ and $\mathrm{P}_{2} \mathrm{O}_{5}$ contents of the sludge and the pulp density employed during the water leaching, the leach liquor may analyse as 8 to $20 \mathrm{~g} / 1$ $\mathrm{V}_{2} \mathrm{O}_{5}$ or higher with a $\mathrm{V}_{2} \mathrm{O}_{5}$ to $\mathrm{P}_{2} \mathrm{O}_{5}$ ratio of 0.6 to 15. Vanadium value can be recovered from such solutions in a variety of ways after adequate purification.

\section{SOLUTION PURIFICATION}

Since sodium vanadate present in the sludge exhibits high solubility in water, repeated leaching of fresh batches of sludge in the same liquor can easily generate a solution containing $20 \mathrm{~g} / \mathrm{l} \mathrm{V}_{2} \mathrm{O}_{5}$ or higher as mentioned earlier. During such a leaching process, concentrations of phosphate, silicate and fluoride also build up considerably. Separation of these impurities is necessary to prevent not only inhibition of precipitation of vanadate salts but also contamination. Purification of the leach liquor is, therefore, an essential step in the recovery of vanadium products. It should, however, be mentioned here that classic methods of purification can serve the purpose adequately and it is not mandatory to introduce a solvent extraction step which is more suited to upgrading and purification of lean solutions. Crystallization and selective precipitation are the two classic methods reported for the separation of phosphate from the vanadium-bearing leach liquors.

In the crystallization process patented / $3 /$ way back in 1948, the highly alkaline solution is partially neutralised prior to separation to disodium phosphate crystals. It was claimed that separation efficiency depended on the ratios of vanadium to phosphorous in the liquor; the higher the ratio of $\mathrm{V}_{2} \mathrm{O}_{5}$ to $\mathrm{P}_{2} \mathrm{O}_{5}$, the better the separation. According to another publication /4/ a $\mathrm{V}_{2} \mathrm{O}_{5}$ to $\mathrm{P}_{2} \mathrm{O}_{5}$ ratio of 1.86 was considered optimum for removal of most of the phosphate. In an investigation conducted by the National Metallurgical Laboratory (NML) of Jamshedpur, India $/ 5 /$, a leach liquor analysed as $8 \mathrm{~g} / 1 \mathrm{~V}$ and $22.7 \mathrm{~g} / 1 \mathrm{PO}_{4}$ was subjected to the crystallization process. It was found to be possible to crystallize out $16.5,54.3$, and $82.8 \%$ of the phosphate by adopting a degree of evaporation on the order of 25,50 and $60 \%$, respectively. These three batches of crystals, however, contained $9.2,39.4$ and $46.2 \%$ of vanadium present in the starting solution. It is, therefore, apparent that crystallization is not an effective means for selective separation of phosphate. Also any effort to partially neutralise the leach liquor before crystallization did not succeed in improving separation efficiency.

The selective precipitation process involves adding $\mathrm{CaCl}_{2}$ to the leach liquor to precipitate phosphorous according to the following reaction:

$2 \mathrm{Na}_{3} \mathrm{PO}_{4}+3 \mathrm{CaCl}_{2} \rightarrow \mathrm{Ca}_{3}\left(\mathrm{PO}_{4}\right)_{2}+6 \mathrm{NaCl}$

In the same work, selective precipitation of phosphate from a leach liquor analysed as $8 \mathrm{~g} / \mathrm{V}$ and 22.7 $\mathrm{g} / 1 \mathrm{PO}_{4}$ was attempted using a stoichiometric amount of $\mathrm{CaCl}_{2}$ as per Eq. 1. It was found that about $75 \%$ of the phosphate could be precipitated at a pH of 6 . The loss of vanadium due to coprecipitation was $6.85 \%$. Phosphate precipitation was found to be more complete as the $\mathrm{pH}$ was graduatly raised beyond 6 and a maximum phosphate precipitation of $88.9 \%$ could be achieved at a $\mathrm{pH}$ of 9 but the corresponding vanadium loss increased significantly to a value of $31.35 \%$. According to work done by the U.S. Bureau of Mines $/ 6 /$, phosphorous and fluoride from a vanadium-bearing carbonate solution could be removed by precipitation with $\mathrm{CaCl}_{2}$ and $\mathrm{MgO}$. The required amount of $\mathrm{CaCl}_{2}$ solution was added at a 
$\mathrm{pH}$ of 8 to precipitate about $75 \%$ of the phosphate. The solution was next made ammonical to raise the $\mathrm{pH}$ to 9 for precipitation of the remaining phosphate by adding $\mathrm{MgO}$. The precipitation process was allowed to be completed by maintaining a temperature of $60^{\circ} \mathrm{C}$. This prescribed procedure, however, did not mention the extent of vanadium loss incurred during the precipitation of phosphate.

\section{PRECIPITATION OF VANADATE SALTS}

Vanadium can be precipitated from the purified solution as a number of vanadate salts. However, salts of technological importance are the only sodium hexavanadate, ammonium metavanadate, ammonium hexavanadate, calcium vanadate and ferrous vanadate.

\section{A. Sodium Hexavanadate}

Sodium hexavanadate represented by the chemical formula $\mathrm{Na}_{2} \mathrm{H}_{2} \mathrm{~V}_{6} \mathrm{O}_{17}$ is known popularly as red cake. The air dried red cake contains 83 to $86 \% \mathrm{~V}_{2} \mathrm{O}_{5}$ and 4 to $11 \% \mathrm{Na}_{2} \mathrm{O}$. This material after fusion is the standard fused black cake of commerce $\Pi /$ used for ferrovanadium production. The precipitation process for red cake is initiated by acidification of the agitated alkaline solution to $\mathrm{pH} 1.5$ to 2.5 when a red coloured colloidal vanadium complex is formed. It undergoes hydration and agglomeration as the slurry is heated to near boiling temperature. Agitation during precipitation lead to formation of round globules which can be easily filtered. More than $99 \%$ of vanadium can be precipitated as red cake according to the following reactions:

$$
\begin{aligned}
& 6 \mathrm{NaVO}_{3}+2 \mathrm{H}_{2} \mathrm{SO}_{4} \rightarrow \mathrm{Na}_{2} \mathrm{H}_{2} \mathrm{~V}_{6} \mathrm{O}_{17}+ \\
& 2 \mathrm{Na}_{2} \mathrm{SO}_{4}+\mathrm{H}_{2} \mathrm{O} \\
& 6 \mathrm{Na}_{3} \mathrm{VO}_{4}+8 \mathrm{H}_{2} \mathrm{SO}_{4} \rightarrow \mathrm{Na}_{2} \mathrm{H}_{2} \mathrm{~V}_{6} \mathrm{O}_{17}+ \\
& 8 \mathrm{Na}_{2} \mathrm{SO}_{4}+7 \mathrm{H}_{2} \mathrm{O}
\end{aligned}
$$

The precipitation efficiency and the composition of the red cake are dependent on the conditions of precipitation, i.e., (i) vanadium content of the alkaline solution, (ii) presence of certain cations, (iii) presence of impurities and (iv) manner and extent of acidification. Red cake precipitation takes place most efficiently when $\mathrm{V}_{2} \mathrm{O}_{5}$ concentration is $20 \mathrm{~g} / 1$ and higher. Low grade solutions with less than $5 \mathrm{~g} / 1 \mathrm{~V}_{2} \mathrm{O}_{5}$ are not amenable to efficient precipitation and requires extended /7/ duration of boiling. In order to permit complete precipitation of vanadium as red cake to take place, sodium content of the solution should be $/ 8 /$ twelve times the theoretical requirement of that present in $\mathrm{Na}_{2} \mathrm{H}_{2} \mathrm{~V}_{6} \mathrm{O}_{17}$. Typically such precipitation at $\mathrm{pH}$ of 1.8 , temperature of 85 to 95 ' $\mathrm{C}$ and duration of 5 hours would yield a red cake analysed as $82.1 \% \mathrm{~V}_{2} \mathrm{O}_{5}, 8.5 \% \mathrm{Na}_{2} \mathrm{O}$ with a $8.4 \%$ loss on ignition. When the red cake is precipitated in the presence of ammonium ions, a mixed ammonium-sodium hexavanadate is obtained. Thus addition of $\mathrm{NH}_{4} \mathrm{Cl}$ to the vanadium solution can reduce the soda content of red cake. Similarly the presence of calcium ion in the vanadium solution can yield a product with $\mathrm{CaO}$. Phosphorous is considered as an undesirable impurity because it affects the precipitation of red cake. If it is present in an excess of $1 \mathrm{~g} /$, vanadium recovery comes down from 99.5 to $85 \%$. Presence of any organic mater also inhibits the precipitation process. Precipitation of red cake takes place at a range of acidity $(\mathrm{pH}-2.5$ to 1.5). The precipitate obtained at high acidity is lower in its soda and phosphorous contents and undergoes less loss on ignition presumably because of an increase in polyacid content of the red cake. Formation of a low soda product also depends on the manner of acidification. For example, when $\mathrm{H}_{2} \mathrm{SO}_{4}$ is added to a cool alkaline solution, a vanadic acid with low soda is formed. This cake, when heated, undergoes hydrolysis and forms a red cake with less than $3 \%$ soda. According to Douglas et al $19 /$, the entire acidification process of the vanadium solution preheated to $60^{\circ} \mathrm{C}$ should be completed within one minute. At this optimum acid dosage, $98 \%$ of vanadium precipitates as red cake of acceptable purity and physical property. The lower limit of dosage is imposed by the production of sour precipitates which are voluminous, difficult to filter and contain $80 \%$ moisture. The upper limit of dosage, on the other hand, is dictated by the extent of solubilisation of the precipitate at low pHs.

\section{B. Ammonium Metavanadate}

The ammonium metavanadate (AMV) route is generally taken if recovery of vanadium in the form of pure $\mathrm{V}_{2} \mathrm{O}_{5}$ is intended. AMV represented by the 
chemical formula $\mathrm{NH}_{4} \mathrm{VO}_{3}$ forms when ammonia or $\mathrm{NH}_{4} \mathrm{Cl}$ or $\left(\mathrm{NH}_{4}\right)_{2} \mathrm{SO}_{4}$ is added to a concentrated $(-100$ $\mathrm{g} / 1 \mathrm{~V}_{2} \mathrm{O}_{5}$ ) vanadium solution at $\mathrm{pH} 8.5$ according to the following reaction:

$\mathrm{NaVO}_{3}+\mathrm{NH}_{4} \mathrm{Cl} \rightarrow \mathrm{NH}_{4} \mathrm{VO}_{3}+\mathrm{NaCl}$

Such a compound on calcination at $450^{\circ} \mathrm{C}$ decomposes to $\mathrm{V}_{2} \mathrm{O}_{5}$ as per the following reaction:

$2 \mathrm{NH}_{4} \mathrm{VO}_{3} \rightarrow \mathrm{V}_{2} \mathrm{O}_{5}+2 \mathrm{NH}_{3}+\mathrm{H}_{2} \mathrm{O}$

AMV precipitation takes place at room temperature because it has a low solubility $(5.2 \mathrm{~g} / \mathrm{l})$ in cold water. Moreover, solubility of this compound decreases with an increase in the concentration of excess $\mathrm{NH}_{4} \mathrm{Cl}$ in the solution. Thus it is the usual practice $/ 8 /$ to add at least $100 \%$ excess of $\mathrm{NH}_{4} \mathrm{Cl}(4.62 \mathrm{~kg} / \mathrm{kg}$ of $\mathrm{V})$ over that required theoretically to form $\mathrm{NH}_{4} \mathrm{VO}_{3}$ for effecting almost quantitative precipitation of vanadium. After the separation of AMV, the tail liquor now contains a large excess of $\mathrm{NH}_{4} \mathrm{Cl}$, and it is necessary to recycle this material for obvious economic reasons by adopting a crystallization technique.

Often the red cake itself acts as a starting material for the production of AMV. It can be dissolved in soda ash solution according to the following reaction:

$\mathrm{Na}_{2} \mathrm{H}_{2} \mathrm{~V}_{6} \mathrm{O}_{17}+2 \mathrm{Na}_{2} \mathrm{CO}_{3} \rightarrow 6 \mathrm{NaVO}_{3}$

$+2 \mathrm{CO}_{2}+\mathrm{H}_{2} \mathrm{O}$

For example $/ 10 /$, a soda ash solution composed of $160 \mathrm{~g}$ of $\mathrm{Na}_{2} \mathrm{CO}_{3}$ in 2.41 water could dissolve $400 \mathrm{~g}$ of red cake in 3 hours at $75^{\circ} \mathrm{C}$ in the presence of $6 \mathrm{~g}$ of sodium chlorate to yield $130 \mathrm{~g} / 1 \mathrm{~V}_{2} \mathrm{O}_{5}$ solution with $99.8 \%$ vanadium recovery.

Addition of $100 \%$ excess of solid $\mathrm{NH}_{4} \mathrm{CI}$ or $\left(\mathrm{NH}_{4}\right)_{2} \mathrm{SO}_{4}$ to the sodium vanadate solution results in 99.7\% vanadium recovey within half an hour. Sometimes AMV can be further purified by adopting a recrystallization technique. The recrystallization procedure consists of the following steps:

i) slurring AMV with a measured quantity of water

ii) acidification of the slurry to $\mathrm{pH} 2$ by adding $\mathrm{H}_{2} \mathrm{SO}_{4}$ to form a $130 \mathrm{~g} / 1 \mathrm{~V}_{2} \mathrm{O}_{5}$ solution

iii) adding $\mathrm{NH}_{4} \mathrm{OH}$ to the solution to raise its $\mathrm{pH}$ to 8 and initiate crystallization. The ammonium metavanadate salt obtained after two hours of recrystallization yields $99.9 \%$ pure $\mathrm{V}_{2} \mathrm{O}_{5}$ after calcination.

\section{Ammonium Hexavanadate}

Besides AMV, ammonium hexavanadate (AHV) as represented by the formula $\left(\mathrm{NH}_{4}\right)_{2} \mathrm{IH}_{2} \mathrm{~V}_{6} \mathrm{O}_{17}$ is yet another ammonium salt of vanadium that can be precipitated by adding $\mathrm{NH}_{4} \mathrm{Cl}$ to an alkaline vanadium-bearing solution after its acidification to a $\mathrm{pH}$ of 1.5 to 2.5 .

$6 \mathrm{NaVO}_{3}+2 \mathrm{H}_{2} \mathrm{SO}_{4}+2 \mathrm{NH}_{4} \mathrm{CI} \rightarrow\left(\mathrm{NH}_{4}\right)_{2} \mathrm{H}_{2} \mathrm{~V}_{6} \mathrm{O}_{17}$

$+2 \mathrm{Na}_{2} \mathrm{SO}_{4}+2 \mathrm{NaCl}+\mathrm{H}_{2} \mathrm{O}$

In contrast to AMV, efficient precipitation of $\mathrm{AHV}$ can take place from a leaner (25 to $30 \mathrm{~g} / 1 \mathrm{~V}_{2} \mathrm{O}_{5}$ ) solution but requires the same amount of $\mathrm{NH}_{4} \mathrm{Cl}$ for near quantitative precipitation of vanadium. However, precipitation of AHV needs a higher temperature of the order of 85 to $95^{\circ} \mathrm{C}$ and a shorter duration of 1.5 to 2.5 hours. It is typically analysed as $83.53 \mathrm{~V}_{2} \mathrm{O}_{5}$ and $53 \mathrm{NH}_{3}$.

\section{Calcium Vanadate}

As mentioned earlier, precipitation of vanadium either as red cake or ammonium vanadate salts requires a solution reasonably strong with respect to its vanadium content. Therefore, such a precipitation process is not applicable to leaner solutions (less than $10 \mathrm{~g} / \mathrm{l} \mathrm{V}_{2} \mathrm{O}_{5}$ ) generated by leaching of low grade vanadium sludges. In this kind of situation, precipitation of calcium vanadate as standardised by Chindgren et al /8/ is an appropriate approach for treating solutions analysed as 7 to $8 \mathrm{~g} / 1$ of $\mathrm{V}_{2} \mathrm{O}_{5}$.

Precipitation of calcium vanadate with a chemical formula of $2 \mathrm{CaO} . \mathrm{V}_{2} \mathrm{O}_{5}$ from a solution with $8 \mathrm{~g} / 1$ $\mathrm{V}_{2} \mathrm{O}_{5}$ can be achieved by adding $50 \%$ excess $\mathrm{CaCl}_{2}$ over that indicated by the following equation at a temperature of 85 to $90^{\circ} \mathrm{C}$ and a $\mathrm{pH}$ of 8 :

$2 \mathrm{NaVO}_{3}+2 \mathrm{CaCl}_{2}+2 \mathrm{NaOH} \rightarrow 2 \mathrm{CaO} \cdot \mathrm{V}_{2} \mathrm{O}_{5}$

$+4 \mathrm{NaCl}+\mathrm{H}_{2} \mathrm{O}$

Almost quantitative precipitation of vanadium as dicalcium vanadate was found to be possible by continu- 
ing agitation and heating of the slurry for two hours. It should be mentioned here that excess calcium chloride is required only for completing precipitation from leaner solutions and addition of a stoichiometric amount of $\mathrm{CaCl}_{2}$ was found adequate for concentrated solutions analysed as say $30 \mathrm{~g} / 1 \mathrm{~V}_{2} \mathrm{O}_{5}$. The calcium vanadate salt is milky white in colour, quite dense and easy to filter.

As far as the utility aspect of such a compound is concerned, it can act as an intermediate for generating a concentrated vanadium solution that can be processed for the recovery of red cake or AMV. Dicalcium vanadate can be readily extracted $/ 8 /$ in an $\mathrm{HCl}, \mathrm{H}_{2} \mathrm{SO}_{4}, \mathrm{Na}_{2} \mathrm{CO}_{3}$ and $\mathrm{NaHCO}_{3}$ solution according to the following reactions to obtain vanadium solutions containing 25 to $125 \mathrm{~g} / \mathrm{l}$ of $\mathrm{V}_{2} \mathrm{O}_{5}$ :

$$
\begin{aligned}
& 3\left(2 \mathrm{CaO} \cdot \mathrm{V}_{2} \mathrm{O}_{5}\right)+12 \mathrm{HCl} \rightarrow \mathrm{H}_{4} \mathrm{~V}_{6} \mathrm{O}_{17} \\
& +6 \mathrm{CaCl}_{2}+4 \mathrm{H}_{2} \mathrm{O} \\
& 3\left(2 \mathrm{CaO} \cdot \mathrm{V}_{2} \mathrm{O}_{5}\right)+6 \mathrm{H}_{2} \mathrm{SO}_{4} \rightarrow \mathrm{H}_{4} \mathrm{~V}_{6} \mathrm{O}_{17}+6 \mathrm{CaSO}_{4} \\
& +4 \mathrm{H}_{2} \mathrm{O} \\
& 2 \mathrm{Ca} \cdot \mathrm{O} \cdot \mathrm{V}_{2} \mathrm{O}_{5}+2 \mathrm{Na}_{2} \mathrm{CO}_{3} \rightarrow \mathrm{NaVO}_{3}+\mathrm{Na}_{3} \mathrm{VO}_{4} \\
& +2 \mathrm{CaCO}_{3} \\
& 2 \mathrm{CaO}_{2} \mathrm{O}_{5}+2 \mathrm{NaHCO}_{3} \rightarrow 2 \mathrm{NaVO}_{3}+2 \mathrm{CaCO}_{3} \\
& +\mathrm{H}_{2} \mathrm{O}
\end{aligned}
$$

For hydrochloric acid dissolution of $17.1 \mathrm{gms}$ of dicalcium vanadate analysed as $35.5 \% \mathrm{CaO}$ and $55.1 \%$ $\mathrm{V}_{2} \mathrm{O}_{5}$, leaching was done with $300 \mathrm{cc}$ water and $17.7 \mathrm{cc}$ conc. $\mathrm{HCl}$ at about $\mathrm{pH} 2$ for half an hour. The leach liquor containing $30 \mathrm{~g} / 1 \mathrm{~V}_{2} \mathrm{O}_{5}$ represents an acid consumption figure of $8.8 \mathrm{~kg}$ of reagent grade acid $(37.5 \%$ $\mathrm{HCl}$ ) per $\mathrm{kg}$ of vanadium. Similarly for $\mathrm{H}_{2} \mathrm{SO}_{4}$ leaching of the same grade of calcium vanadate, $24 \mathrm{~g}$ of the salt can be dissolved in dilute acid consisting of 514 cc water and $8.2 \mathrm{cc} 96 \% \mathrm{H}_{2} \mathrm{SO}_{4}$ at room temperature after half an hour leaching. In order to avoid any loss of vanadium with gypsum precipitate, the temperature was not allowed to go beyond $30^{\circ} \mathrm{C}$ and filtration was followed immediately after leaching. It was found to be possible to generate a solution analysed as $25 \mathrm{~g} / 1 \mathrm{~V}_{2} \mathrm{O}_{5}$ by consuming $4.62 \mathrm{~kg}$ of conc. $\mathrm{H}_{2} \mathrm{SO}_{4}$ per $\mathrm{kg}$ of vanadium dissolved. A three-hour soda ash leach at 85 to $95{ }^{\circ} \mathrm{C}$ with $50 \%$ excess $\mathrm{Na}_{2} \mathrm{CO}_{3}$ can dissolve $99.8 \%$ vanadium present in the vanadate salt and yield a highly alkaline ( $\mathrm{pH} \mathrm{12)} \mathrm{solution} \mathrm{with} 89 \mathrm{~g} / 1 \mathrm{~V}_{2} \mathrm{O}_{5}$. Leaching with $25 \%$ excess $\mathrm{Na}_{2} \mathrm{CO}_{3}$ at room temperature with bubbling of $\mathrm{CO}_{2}$ gas for the same period results in a 99 $\mathrm{g} / 1 \mathrm{~V}_{2} \mathrm{O}_{5}$ solution of $\mathrm{pH} 8.4$ which was found to be more suited to subsequent AMV precipitation. Soda ash consumption is $5.94 \mathrm{~kg}$ per $\mathrm{kg}$ vanadium dissolved. Leaching with $\mathrm{NaHCO}_{3}$ at room temperature yields results comparable to that with $\mathrm{Na}_{2} \mathrm{CO}_{3}$ but the use of the former poses the problem of frothing due to $\mathrm{CO}_{2}$ evolution. In addition to acting as an intermediate for the preparation of AMV, calcium vanadate can also be used directly for the production of ferrovanadium discussed later in this paper.

\section{E. Ferrous Vanadate}

As with calcium vanadate, it is also possible /11/ to precipitate vanadium as ferrous vanadate salt by adding ferrous sulphate salt according to the following equation:

$2 \mathrm{NaVO}_{3}+\mathrm{nFeSO}_{4}+2(\mathrm{n}-\mathrm{l}) \mathrm{NaOH} \rightarrow \mathrm{nFeO} . \mathrm{V}_{2} \mathrm{O}_{5}$

$+\mathrm{nNa}_{2} \mathrm{SO}_{4}+(\mathrm{n}-\mathrm{l}) \mathrm{H}_{2} \mathrm{O}$

where ' $\mathrm{n}$ ' stands for the mol ratio of $\mathrm{FeO}$ to $\mathrm{V}_{2} \mathrm{O}_{5}$. It was found to be possible to precipitate compounds with values of ' $n$ ' at around 2 and 3 by using an essentially stoichiometric amount of ferrous sulphate and a $\mathrm{pH}$ in the range of 7 to 9 . Precipitation of a compound with a higher value of 4 for $n$ was achieved only when the $\mathrm{pH}$ was raised to 12 . In a typical precipitation experiment, adding $6.7 \mathrm{~kg} \mathrm{FeSO} 4.7 \mathrm{H}_{2} \mathrm{O}$ for every $\mathrm{kg}$ of vanadium present in the sludge-leach liquor yields a product analysed as $53 \% \mathrm{~V}_{2} \mathrm{O}_{5}$ and $44 \% \mathrm{FeO}$. Recovery of such ferrous vanadate salt is justifiable if one intends to use it for ferrovanadium production.

\section{CONVERSION OF VANADIUM COMPOUNDS TO METALLIC PRODUCTS}

Among the metallic vanadium products, the leading one is ferrovanadium which has found maximum use in industry. Next to ferrovanadium, the other important commercial products of vanadium are the aluminium alloys. These alloys have been established as useful in making titanium base alloys for aerospace applications 
(Ti-6Al-4V is a well-known member of this group). Besides these two kinds of alloys, ferrovanadium and vanadium-aluminium, ductile grade pure vanadium metal also has specific technological applications. Both vanadium alloys are similar in their methods of production in that both essentially involve the reduction of $\mathrm{V}_{2} \mathrm{O}_{5}$ with aluminium - the metal whose extraction from bauxite ore incidentally leads to the generation of vanadium sludge as explained earlier.

\section{A. Ferrovanadium}

Production of low carbon ferrovanadium analysed as 35 to $75 \% \mathrm{~V}, 1.5 \% \max \mathrm{Si}, 0.2 \% \max \mathrm{C}, 0.1 \% \max \mathrm{S}$, $0.1 \% \max \mathrm{P}$, and $1.5 \% \max \mathrm{Al}$ is done by aluminothermic reduction of $\mathrm{V}_{2} \mathrm{O}_{5}$ available in the form of black cake or calcined AMV/AHV.

Primary reduction of $\mathrm{V}_{2} \mathrm{O}_{5}$ with $\mathrm{Al}$ is thermodynamically highly favourable and strongly exothermic in nature as indicated by the data presented for reaction No. 14 in Table 1. The specific heats or the degree of exothermicity of the charge is rather on the high side for the safe and efficient conduct of the reduction run. The situation, however, changes greatly as lime is added to the thermit charge as a flux (refer to reaction No. 15). Addition of an adequate quantity of lime makes the reaction thermodynamically slightly more favourable, brings down the specific heat of the charge and more importantly reduces the melting point of the slag phase from 2050 to $1720^{\circ} \mathrm{C}$. This in effect improves the fluidity of the slag phase which greatly facilitates slag/metal separation. In the context of adding lime as flux in the thermit charge, partial or full replacement of $\mathrm{V}_{2} \mathrm{O}_{5}$ by $2 \mathrm{CaOV}_{2} \mathrm{O}_{5}$ as a dual source of $\mathrm{V}_{2} \mathrm{O}_{5}$ and lime becomes an attractive proposition. Since, in this case, lime is available in the chemically bound form with $\mathrm{V}_{2} \mathrm{O}_{5}$, it is readily available for the fluxing purpose $/ 12 /$ during the reduction reaction. As an alternative to adding iron scrap, incorporation of ferrous vanadate $/ 11 /$ in the thermit charge appears to be an interesting possibility wherein coreduction of $\mathrm{Fe}$ and $\mathrm{V}$ oxides present as $2 \mathrm{FeO} . \mathrm{V}_{2} \mathrm{O}_{5}$ according to the following reaction

$$
2 \mathrm{FeOV}_{2} \mathrm{O}_{5}+14 / 3 \mathrm{Al} \rightarrow 2(\mathrm{Fe}-\mathrm{V})+7 / 3 \mathrm{Al}_{2} \mathrm{O}_{3}
$$

yields ferrovanadium with 40 to $50 \%$ vanadium. Con- sidering the more established practice of adding iron via scrap, it can be seen from reaction No. 16 that specific heat has further decreased to $758 \mathrm{~K} \mathrm{cal} / \mathrm{kg}$ of the charge. In addition to a low melting slag, the reaction now yields an alloy phase with a much lower liquidus temperature of $1570^{\circ} \mathrm{C}$. The likelihood of good slag/alloy separation is, therefore, enhanced significantly. Typically a thermit charge composed of $1 \mathrm{~kg} \mathrm{~V} \mathrm{O}_{5}, 0.49 \mathrm{~kg}$ $\mathrm{Al}, 0.0256 \mathrm{~kg} \mathrm{CaO}$, and $0.373 \mathrm{~kg}$ Fe scrap is expected to yield $60 \mathrm{~V}-40 \mathrm{Fe}$ alloy with about $95 \%$ vanadium recovery. In actual practice, however, 5 to $10 \%$ excess aluminium over that required stoichimetrically is always added to achieve high alloy yield. Incorporation of aluminium should be in no case much higher than the stoichiometric amount produced as the aluminium content of the ferroalloy may exceed the specific limit. Some ferroalloy manufacturers prefer to use $\mathrm{CaF}_{2}$ as flux in place of $\mathrm{CaO}$ to achieve more or less the same liquidus temperature for the slag phase. In contrast to lime, $\mathrm{CaF}_{2}$ has incidentally a much lower melting point of $1418^{\circ} \mathrm{C}$ and is said to reduce $/ 13 /$ the viscosity of alumina slag tro an appreciable extent.

Besides the charge composition, proper selection of particle sizes of $\mathrm{V}_{2} \mathrm{O}_{5}, \mathrm{Al}$ and fluxes has an important bearing on the outcome of the reduction process. A too fine-sized $\mathrm{Al} / 14$ / reacts at an extremely fast rate and generates the highest peak temperature but more importantly the reacted charge remains molten for a relatively short duration badly affecting the separation of the alloy prills from the slag phase. Too coarse an aluminium powder, on the other hand, results in a slow reaction, low peak temperature and hence poor slag/metal separation. Medium-sized aluminium powder with average particle size between 125 to $420 \mu \mathrm{m}$ allows the slag to remain in the highly fluid condition for the longest duration and should, therefore, be chosen for ferrovanadium production. Particle size of the fluxes should be small enough for forming an uniform slag phase. Large particles invariably separate out as the reaction proceeds, create a variable reaction and badly affect the apparent viscosity of the slag. As far as adding iron to the charge is concerned, scrap should be in a small enough size for easy mixing.

Aluminothermic reduction practised for ferrovanadium is essentially a nonfurnace process and is done 


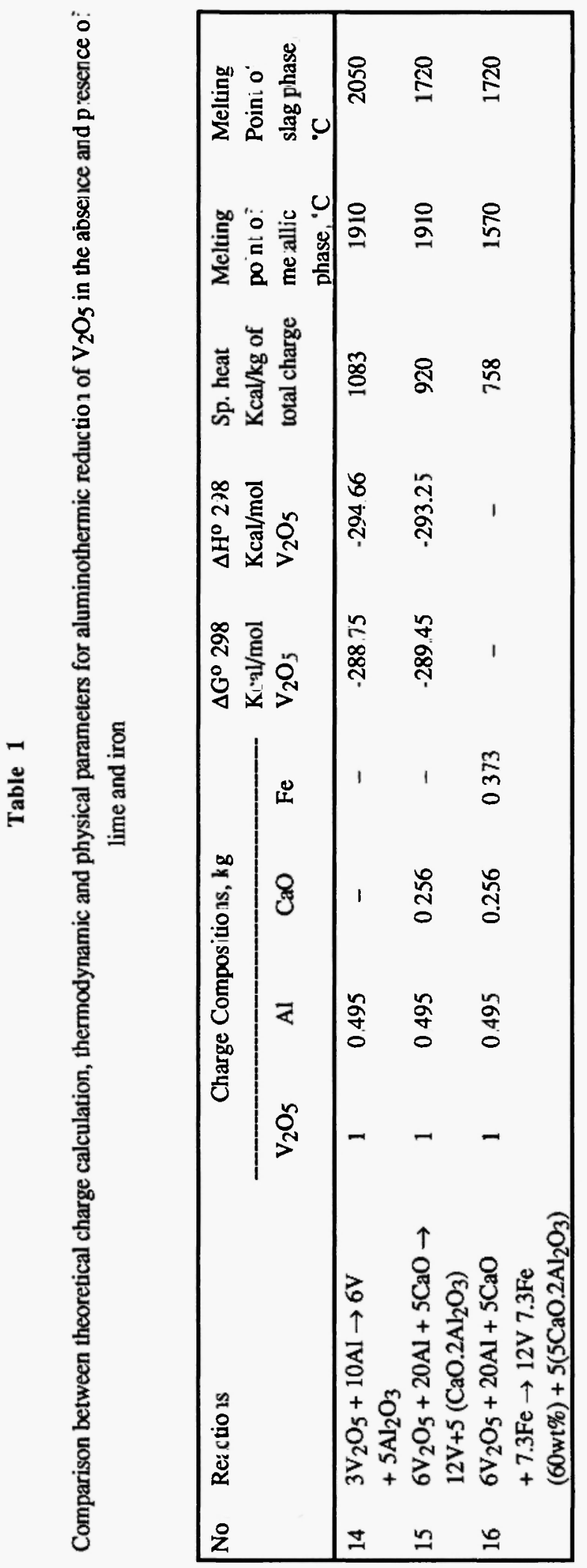


in a refractory lined reactor. The reactor consists of two components. The first is a both side open steel cylindrical slice lined first with insulating bricks and then with magnesite bricks to make a mildly tapered cavity. Sometimes the inner magnesia brick lining can be smoothed out by giving a coating of slurry of dead burnt magnesia powder/ground slag in water and sodium silicate. The diameter and height of the reactor are decided on the scale of operation. Some ferroalloy manufacturers prefer to use a large diameter to height ratio so that a relatively thin disc of alloy is obtained. Although such thinner discs are easy to crush, the radiation loss through the large open mouth of the reactor is rather high. The lined shell is placed on the sand bed of a mould box and a layer of $\mathrm{MgO}$ powder/ground slag is provided at the bottom of the reactor. Such a reactor design makes the removal of the alloy and slag from the reactor and their separation quite easy because both sides of the lined shell can be approached for freeing it from the reacted material.

Initiation and completion of the thermit reaction can be accomplished by adopting two different techniques, namely bottom and top priming. In the bottom priming mode, a small part of the thermit charge is placed at the bottom of the reactor. A trigger or starter mixture composed of $\mathrm{KClO}_{3}$ and Al powder mixed in the weight ratio of $3: 1$ is sprinkled liberally on the top of the thermit charge. A burning magnesium stick is planted on the charge to initiate the reaction between $\mathrm{KClO}_{3}$ and $\mathrm{Al}$ which in turn triggers the primary reaction. Once the primary reaction proceeds vigorously, the remaining charge is added at a controlled rate through a chute. In the top priming technique, on the other hand, the entire charge is placed at one time in the reactor and the reaction is triggered from the top. Between these two techniques, the former is preferred for a relatively large scale of operation as the reactor volume is more effectively utilised. Moreover, the bottom primed reaction is characterised by a longer reaction period, fairly uniform evolution of gases throughout the reaction period and less ejection of the charge out of the reactor.

\section{B. Vanadium-Aluminium Alloys}

Different grades of vanadium-aluminium alloys analysed as 2 to $15 \mathrm{wt} \% \mathrm{Al}$ can be produced by adopting reaction Nos. 14 or 15 after incorporating the required amount of excess aluminium in the charge.

Altough the chemical reaction involved in alloy making remains essentially the same, the mode of conducting the reaction in various types of reactors influence the composition and purity of the product. In fact, reduction has been done in reactors belonging to three basic design concepts, namely, (i) an open reactor as described for FeV production, (ii) a bomb-type sealed reactor and (iii) a water-cooled copper reactor.

The bomb-type reactor is essentially a refractory lined thick-walled cylindrical reactor which can be closed from the top by bolting down a suitable flange with provision for the introduction of an electrical triggering device. This type of reactor simulates near adiabatic conditions by conserving heat, does not allow the reactants to escape from the reaction zone and excludes atmospheric contamination of the product. Scaling up the operation in a bomb-type of reactor is, however, quite problematic and poses the hazard of accidents in case of failure of the lining. The enormous development of pressure in a sealed reactor is sometimes avoided by doing the reaction in a reactor that permits flow of inert gas at atmospheric pressure. The water-cooled copper reactor tackles the problem of the reaction of the lining material with the superhot metal/alloy phase by altogether avoiding the former. No doubt considerable amount of reactor heat is lost by conduction, but one can afford to lose some heat as the $\mathrm{V}_{2} \mathrm{O}_{5}$ - $\mathrm{Al}$ reaction is very strongly exhothermic. Moreover, evacuation of the charged reactor and its back purging with inert gas to exclude atmospheric contamination become easier and more efficient. Table 2 presents the results of a typical aluminothermic reduction runs for $\mathrm{V}_{2} \mathrm{O}_{5}$ in different types of reactors as shown in Fig. 2. The two notable trends apparent from such results as presented in Table 2 are the interrelation between the $\mathrm{Al}$ and $\mathrm{O}_{2}$ contents of the alloys and the role of the atmosphere in controlling the nitrogen content of the as reduced alloys. It can be seen from Table 2 that the $\mathrm{O}_{2}$ and $\mathrm{Al}$ contents of the as reduced alloys have an inverse relationship. The oxygen level in the alloy can be brought down significantly by loading vanadium with a higher amount of aluminium. Thus a V-Al alloy with $15.5 \% \mathrm{Al}$ has an $\mathrm{O}_{2}$ content of 

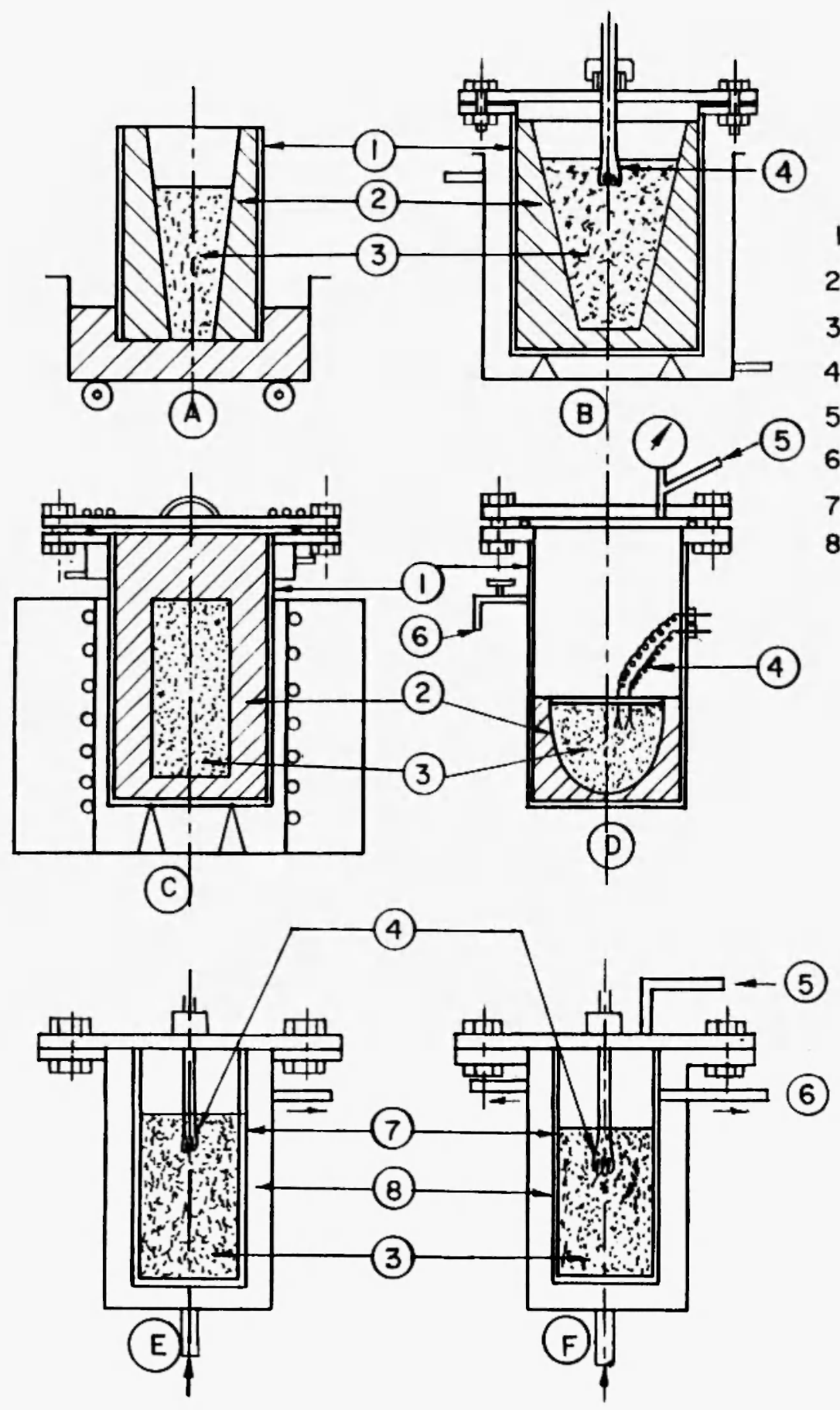

Fig. 2: (a) Open reactor, (b) closed bomb, externally heated to triggering, without argon flushing; (c) closed bomb, externally heated to triggering, argon flushed and sealed; (d) modified bomb, electrically triggered, argon flushed and sealed; (e) water cooled copper reactor, electrically triggered, argon flushed and sealed; $(f)$ water-cooled copper reactor, flowing argon atmosphere.
I. STEEL REACTOR

2. REFRACTORY

3. CHARGE

4. ELECTRICAL TRIGGER

5. ARGON INLET

6. ARGON OUT LET

7. COPPER REACTOR

8. WATER COOLED JACKET.

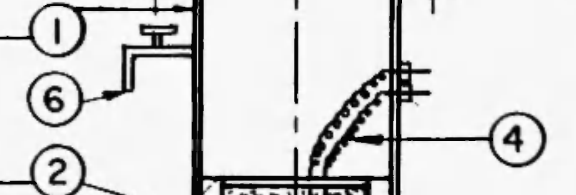

(3)

(p)<smiles>[BH3-]</smiles>

\section{(6)}




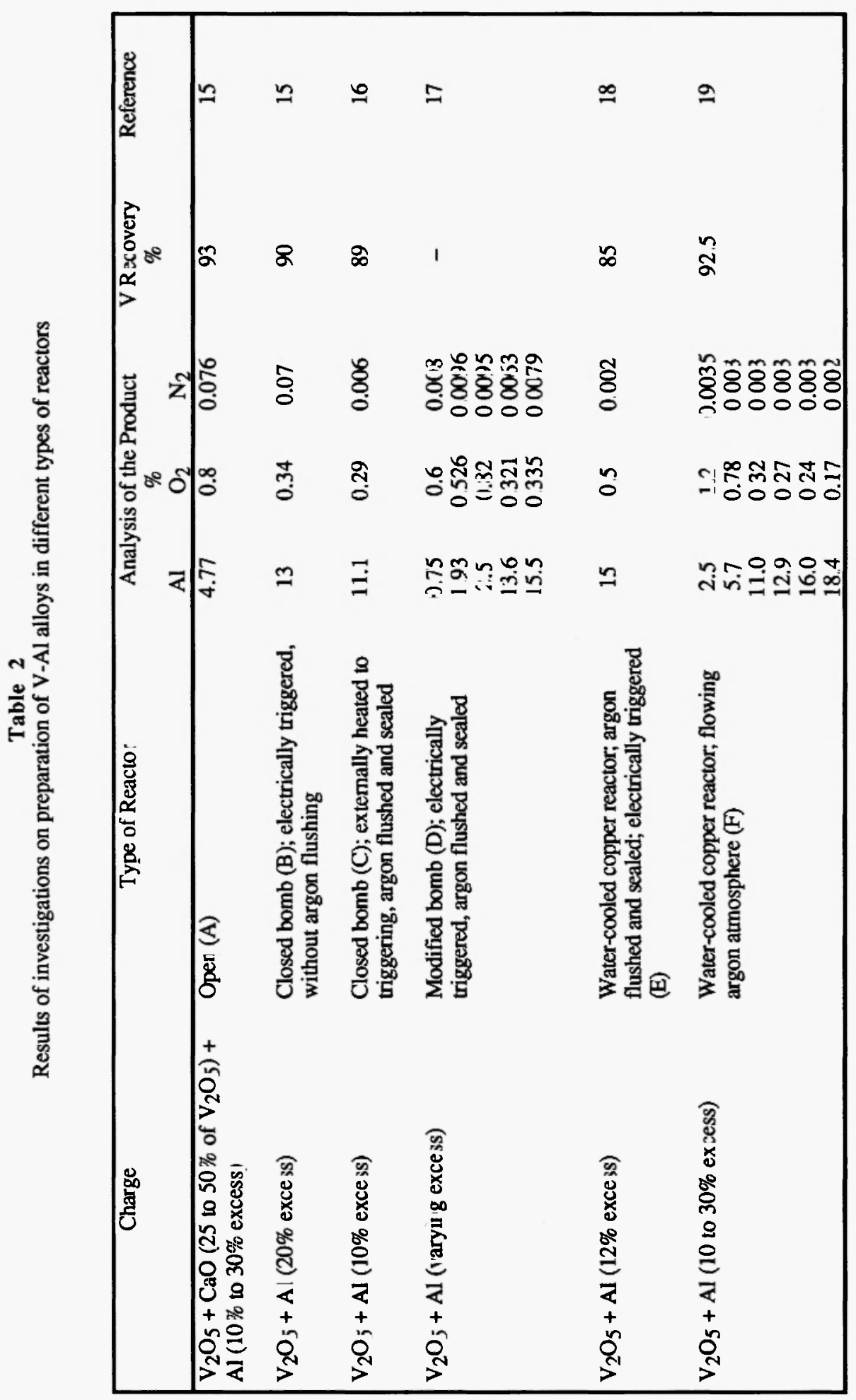


$0.335 \%$. It is interesting to note that lime is not incorporated in the charge in the bomb-type reaction and vanadium recovery is always less than $90 \%$. Open aluminothermic reduction in the presence of lime, on the other hand, yields better vanadium recovery but less $\mathrm{Al}$ loading at the same excess of aluminium in the charge of $\mathrm{V}_{2} \mathrm{O}_{5}$. The open aluminothermic reduction always yields an alloy with high $\mathbf{N}_{2}$ content picked up from the atmosphere. The only way to reduce this particular interstitial impurity to a low level is to exclude the air from the reactor and seal it in inert atmosphere. It is also possible to maintain a flowing inert atmosphere for avoiding pressure build-up and allowing the cooling process to take place in a protective atmosphere.

\section{REFINING OF VANADIUM-ALUMINIUM ALLOYS TO DUCTILE GRADE VANADIUM}

The various grades of aluminothermic vanadium can be broadly divided into two groups: (1) low vanadium ( $-90 \%$ ) alloys with low $\mathrm{O}_{2}$ and $\mathrm{N}_{2}$ content and (2) high vanadium ( $-95 \%$ ) alloys with high $\mathrm{O}_{2}$ and $\mathbf{N}_{2}$ content. Techniques for conversion of such alloys to ductile grade, $99.9 \%$ pure vanadium metal are also entirely different involving electron beam melting with or without prior pyrovacuum treatment for the former and molten salt electrofying for the latter.

\section{A. Electron Beam Melting}

When $\mathrm{V}-\mathrm{Al}$ alloys with more than $10 \% \mathrm{Al}$ and less than $0.4 \% \mathrm{O}_{2}$ are subjected to direct electron beam melt refining, simultaneous removal of $\mathrm{Al}$ and $\mathrm{O}_{2}$ takes place due to distillation of suboxides of $\mathrm{Al}$ like $\mathrm{AI}_{2} \mathrm{O}$ and $\mathrm{AlO}$ which have much higher vapour pressures than $\mathrm{V}$ at its melting point. Presence of sufficient concentration of $\mathrm{Al}$ in the alloy is necessary not only to keep the $\mathrm{O}_{2}$ content at low levels but also to effect its removal during melting. For example, a two-stage electron beam melting of $\mathrm{V}-15.5 \mathrm{Al}$ alloy with $0.35 \% \mathrm{O}_{2}$ reduces the $\mathrm{Al}$ and $\mathrm{O}_{2}$ content to $0.044 \%$ and $0.02 \%$, respectively. It should be mentioned here that in contrast to aluminium deoxidation, sacrificial deoxidation is not that effective in vanadium purification. As far as nitrogen is concerned, its removal by electron beam melting is not at all possible due to the extreme stability of vanadium nitride. Each stage of melting, therefore, progressively increases the nitrogen content of the metal, making it mandatory to use a feed with as low a nitrogen content as possible. Among the metallic elements which are less refractory than vanadium, only silicon resists its removal from vanadium during the melting process. Table 3 presents the extent of purification achieved by electron beam melt refining of A-VI alloys.

The direct electron beam melting of such V-Al alloys is associated with vaporisation and sputtering process due to the presence of large quantities of $\mathrm{Al}$ in the charge. This kind of melt refining treatment should, therefore, be done in furnaces with transverse gun. The deflected beam in this case does not get hindered greatly by the ionized gases. As a result, large scale melt refining of V-Al alloys in a furmace of $650 \mathrm{~kW}$ rating was done $/ 17 /$ to produce $99.93 \%$ pure vanadium ingots weighing as much as 1.1 ton. However, the overall vanadium losses even in such furnaces were reported to be quite significant (see Table 3). As an altemative to direct electron beam melting, incorporation of a pyrovacuum treatment of the alloy in solid state as recommended by Carlson et al $/ 16,18$ / yields a vanadium sponge that undergoes subsequent electron beam melting smoothly and without much metal loss. In this modified procedure, the $\mathrm{V}-11 \% \mathrm{Al}$ alloy is crushed to about 6 $\mathrm{mm}$ size, charged in a vacuum induction furnace with tantalum susceptor and heated at $100^{\circ} \mathrm{C}$ for 8 hours under a dynamic vacuum of $5 \times 10^{-5}$ torr to remove the major fractions of $\mathrm{Al}$ and $\mathrm{O}_{2}$ (see Table 3 ). The electron beam cast vanadium ingots with low levels of interstitial impurities exhibit low hardness on the order of 60-70 VPN and excellent room temperature ductility by undergoing $96 \%$ reduction in thickness without any intermediate annealing.

\section{B. Fused Salt Electron Refining}

As mentioned earlier, open aluminothermically reduced vanadium with high nitrogen content cannot be refined to ductile grade metal by electron beam melting, and fused salt electrorefining happens to be an effective technique for purification of thermit metal /15/ with respect to metallic and other nonmetallic impurities. 


\begin{tabular}{|c|c|c|c|c|}
\hline 迎 & & $=$ & 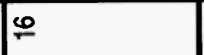 & $\infty$ \\
\hline 总 & & $\begin{array}{l}\text { S. } \\
\text { o: } \\
\text { g }\end{array}$ & $\ddot{8}$ & 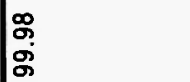 \\
\hline 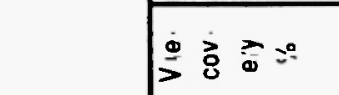 & & $\overline{8} \approx$ & & $\begin{array}{l}n \\
\dot{\rho} \\
\dot{\rho}\end{array}$ \\
\hline 要 & $z$ & 要 & 㑒 & 㖞 \\
\hline 总 & 0 & $\begin{array}{ll}2 \\
0\end{array}$ & 年 & 范 \\
\hline 总 & $\delta$ & $\begin{array}{l}\infty \\
\frac{0}{0} \\
0\end{array}$ & 告 & 里 \\
\hline$\frac{\frac{6}{6}}{\frac{0}{0}}$ & ळ & 䑻 & 趈 & 蒿 \\
\hline 永 & \& & 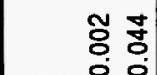 & D. & $\overline{8}$ \\
\hline$\sum_{0}^{\circ}$ & $z$ & & 萬 & 电 \\
\hline m & 0 & & 1 & \%̊요 \\
\hline & $\sigma$ & & 犃 & 彎 \\
\hline 兽 & क & & 象 & ¿̊̀ \\
\hline 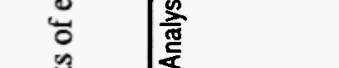 & $<$ & & $\stackrel{\Im}{\Im}$ & ?ִ \\
\hline 芴 & $z$ & \% & 怘 & סे \\
\hline$\frac{\frac{\partial}{\sigma}}{\frac{\pi}{\alpha}}$ & $0 \mid$ & 꿍 & 兹 & \% \\
\hline 题 & 。 & స్ల్ర & ণ্ণু & in \\
\hline 㞸 & का & 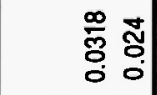 & $\ddot{\circ}$ & $\tilde{8}$ \\
\hline & \& & 象菅 & $\Xi$ & 으 \\
\hline 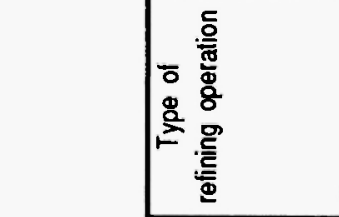 & & 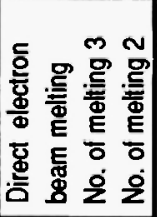 & 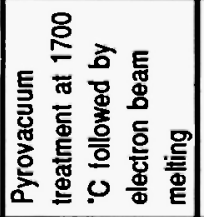 & 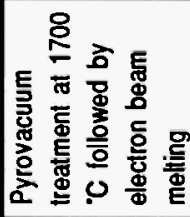 \\
\hline
\end{tabular}


The refining cell consists of thermit vanadium as the anode, molybdenum metal rod as the cathode and a molten chloride bath composed of functional $\left(\mathrm{VCI}_{2}\right)$ and auxiliary (KCl-NaCl/KCl-LiCl) electrolytes. As electrolysis progresses at chosen cathode current density, vanadium ions $\left(\mathrm{V}^{+2}\right)$ present in the electrolyte around the cathode get reduced and deposition of elemental vanadium takes place. Depletion of vanadium ions from the bath due to this cathodic process is compensated by the supply of $\mathrm{V}^{2+}$ made available by oxidation of vanadium present in the anode feed. Since the anode and cathode processes are just the reverse of each other, electrolysis takes place at very little applied potential mainly to take care of the IR drop in the electrolyte and polarisation if any at the electrodes. Those metallic impurities which are nobler with respect to vanadium are not likely to dissolve in the electrolyte. They are retained by the anode. Only baser impurity elements like aluminium are dissolved and may eventually get transferred to the cathode if their concentrations in the electrolyte and cathode potential are favourable. As far as interstitial impurities like $\mathrm{O}_{2}, \mathrm{~N}_{2}$ and $\mathrm{C}$ are concerned, they are present in the anode as oxide, nitride and carbide, respectively. Since these species have very little solubilities in a chloride bath, vanadium metal depositing at the cathode does not get contaminated.

Keeping in mind the highly hygroscopic nature of the chloride electrolyte and the sensitivity of vanadium towards interstitial impurities at elevated temperatures, specially designed inert atmosphere electrorefining cells have been put in use for carrying out semicontinuous operations. The electrolyte is contained in a high density graphite crucible. The anode feed crushed to about $12 \mathrm{~mm}$ size is charged in the annular space between the graphite crucible and a cylindrical perforated molybdenum sleeve. This arrangement ensures a large and uniform anode surface area around the molybdenum cathode rod. A flowing argon atmosphere is maintained throughout the process of melting, electrolysing and cooling of the electrolyte. A slide valve incorporated between the main electrolyte chamber and the water cooled receiver lock allows periodical removal of the deposit, its rapid cooling under inert atmosphere and introduction of a new cathode without exposing the molten electrolyte to open atmosphere. The operational data for a typical refining operation in $\mathrm{KCl}-\mathrm{NaCl}-\mathrm{VCl}_{2}$ electrolyte as well as comparison of the analysis of the feed and the refined product are presented in Tables 4 and 5 , respectively. It can be seen that the major impurityaluminium present in the anode feed is removed to quite a low level. Substantial purification is also achieved for impurities like oxygen, nitrogen and silicon. The average purity of the refined metal is on the order of 99.6\%. The electrolytic product is a mixture of dendritic vanadium crystals as well as powder which can be used as such for specific applications or consolidation by arc melting to ingots.

\section{CONCLUSIONS}

Bayer sludge, a waste generated by aluminium extraction industries in certain countries, is an important resource for vanadium. The sludge contains vanadium in water soluble form and hence simple water leaching can yield a vanadium-bearing solution. The first step towards recovery of the vanadium value from such a solution is the removal of the major impurity, phosphate. After the removal of phosphate by precipitation at controlled $\mathrm{pH}$, vanadium can be recovered in the form of its various compounds, namely, sodium hexavanadate (red cake), ammonium hexavanadate, ammonium metavanadate, calcium vanadate and ferrous vanadate. These compounds can be next converted to two types of metallic products, namely, ferrovanadium and vanadiumaluminium alloy, by adopting an aluminothermic reduction technique. Conversion of vanadium-aluminium alloys to ductile grade vanadium metal by either electron beam melt refining or molten salt electrorefining is the final step in the entire processing scheme as summarised in Fig. 3. For further reading regarding vanadium extractive metallurgy, we recommend the literature cited in Gupta et al /19/. 


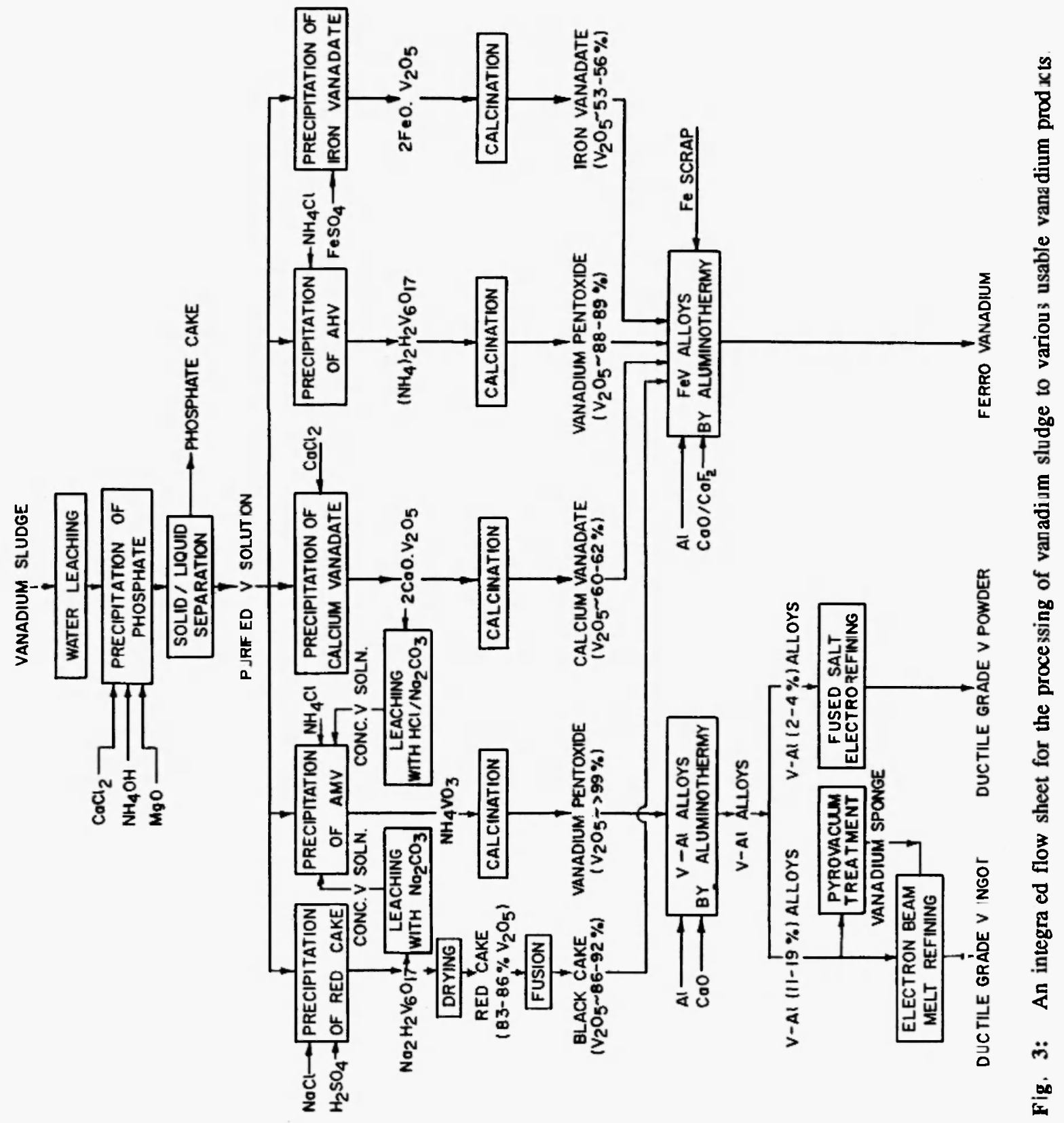


Table 4

Operating data for electrorefining of $\mathrm{V}-\mathrm{Al}$ alloy

1. Electrolyte

2. Vanadium concentration in the bath

3. Cathode current density

4. Voltage

5. Duration of electrolysis

6. Anode feed

7. Cathode recovery

8. Cathode current efficiency

9. Bath temperature

10. Hardness of the arc cast refined vanadium

\section{$\mathrm{KCl}-\mathrm{NaCl}-\mathrm{VCl}_{2}$}

$\begin{array}{lc}\text { wt\% } & 6.7 \\ \text { amp/m2 } & 4444 \\ & 0.6 \\ \text { AH } & 2800 \\ \text { kg } & 2.5 \\ \text { kg } & 2 \\ \% & 75 \\ \text { 'C } & 750\end{array}$

R

Table 5

Analysis of aluminothermic vanadium as anode feed and electrorefined vanadium

\begin{tabular}{|lcccccccccc|}
\hline & $\mathrm{Al}$ & $\mathrm{C}$ & $\mathrm{Cr}$ & $\mathrm{Cu}$ & $\mathrm{Fe}$ & $\mathrm{Mg}$ & $\mathrm{Ni}$ & $\mathrm{N}$ & $\mathrm{O}$ & $\mathrm{Si}$ \\
\hline Anode fused & 47700 & - & - & - & 4200 & - & - & 760 & 800 & 4400 \\
Refined vanadium & 100 & 20 & 600 & 300 & 1500 & 50 & 50 & 30 & 900 & 50 \\
\hline
\end{tabular}

\section{REFERENCES}

1. Gupta, C.K., Int. Metals Reviews, 29, 405 (1984).

2. Private communication with $\mathrm{M} / \mathrm{s}$. HINDALCO.

3. British Patent 600833, April 20 (1948).

4. Veres, I., Ung. Z. Chem., 57, 225 (1951), C.432 (1953).

5. Mahanty, M.S. Dey, T.C., Srinivasan, S.R. and Bhatnagar, P.P., NML Technical Journal, Nov. 9 (1967).

6. Koerner, E.L. and Lucid, M.F., Presented at the Annual Meeting of the Am. Inst. Min. Met. and
Petroleum Engineers, Washington DC, Feb. 20 (1969).

7. Būrwell, B., J. Metals, 562, Aügüst (1961).

8. Chindgren, C.J., Bauerle, L.C. and Shibler, B.K., U.S. Bur. Mines Dept. Invst. 7058, Dec. (1967).

9. Douglas, W.D., Bovey, H.J. and Temple, D.A., J. South Afr. Inst. Min. Met., 385, April (1968).

10. Chindgren, C.J., Bauerle, L.C. and Rosenbaum, J.B., U.S. Bur. Mines Dept. Inst., 5937 (1962).

11. Pattnaik, S.P., Mukherjee, T.K. and Gupta, C.K., Met. Trans., 14B, 133 (1983). 
12. Mehra, O.K. and Gupta, C.K., Met. Trans., 8B, 683 (1977).

13. Mohanty, U.K., Behera, R.C. and Mohanty, A.K., in: Proc. National Seminar on Ferro Alloy Making, S. Ghoshetal (Ed.), RRL, Bhubaneswar, India, 167 (1989).

14. Belitskus, D., J. Metals, 39, May (1973).

15. Pillai, P.V.S., Nair, K.U., Mukherjee, T.K. and Gupta, C.K., Trans. Ind. Inst. Met., 26 (6), 24 (1973).

16. Carlson, O.N., Schmidt, F.A. and Krupp, W.E., $J$. Metals, 18, 320 (1966).
17. Wang, C.T., Baroch, E.F., Worcestor, S.A. and Shen, Y.S., Met. Trans., 1, 1683 (1970).

18. Carlson, O.N., Burkholder, H.R., Martsching, G.A. and Schmidt, F.A., Proc. Extractive Metallurgy of Refractive Metals, H.Y. Sohn, O.N. Carlson and J.T. Smiths (Eds.), Met. Soc. of AIME, Warrandale, PA, 191 (1980).

19. Gupta, C.K. and Krishnamurthy, N., Extractive Metallurgy of Vanadium, Book to be published by Elsevier, Amsterdam 1991). 